withdrew objections to releasing those documents - a third of the total already released by Representative Henry A. Waxman (Democrat, California). That material consists primarily of scientific studies on the addictive nature of nicotine and other health hazards related to smoking. UCSF officials said they will make those documents available on the Internet so they can be widely distributed.

Until a large volume of material can be electronically converted, they will be available during certain hours to researchers who contact the special collections department beforehand. The documents have been returned to the library.

"These documents show that the tobacco industry had a sophisticated understanding of nicotine and nicotine addiction well before the general scientific community understood it," says Stanton Glantz, professor of medicine at UCSF and an authority on the effects of tobacco smoke. "I look forward to the university prevailing in the suit concerning the remainder of the material."

Glantz received the documents in an unsolicited and unmarked package in the spring of last year and transferred them to the university archives. Several other institutions as well as members of Congress also received copies. In February, the tobacco company, claiming the documents were photocopies made by their own law firm and stolen by an assistant paralegal, asked for a temporary restraining order to prevent further distribution and for their return and began its alleged 'stakeout' in the library.

The university threatened to have the private detectives physically removed from UCSF property, and they were temporarily withdrawn. They reportedly returned again a few weeks later. The court denied an immediate restraining order and, over the objections of Brown \& Williamson, has let the university keep the material until a decision is made.

Glantz, an anti-smoking crusader, said he was "very proud that the university is standing up against Brown \& Williamson and defending the public interest and the principle of academic freedom."

Neither the tobacco company nor lawyers from the San Francisco law firm that represents it would comment.

JOEL SHURKIN

San Francisco

\title{
Oversight for tissue transplants
}

French government officials - still smarting from the contaminated blood scandal of the late 1980 s - have been considering whether to put its tissue transplant programme on hold temporarily after allegations came to light that some material currently being used for transplant purposes is not only being purloined but also might be contaminated. But, as a result of a study commissioned by the newly formed office for the oversight of transplants, which looked at the extent of the problem and the relative risks and benefits associated with transplants, the government has decided to hold off with a ban for now.

Among the many disclosures regarding tissue transplants over the past 10 months has been the discovery of several underground networks supplying corneas for transplants from unknown sources. Some of the corneas are reportedly coming from Latin American countries, where they are allegedly being purloined from young children. It is believed that supplies may also be coming from Eastern Europe. In any event, there are no guarantees that the tissue has been checked for viral contamination.

In addition to the elicit trade in corneas, a number of embezzlement schemes have been uncovered in Southern France. Private companies were billing local hospitals and clinics for synthetic bone and ligament tissue, which, as it turned out, came from human sources and, as such, would not be covered by the national health insurance scheme. Where this tissue was coming from and whether it was contaminated or not is still not known.

The situation in France has become so alarming that the new oversight office, the Etablissement Français des Greffes, Paris, set up by the Ministry of Health last December to oversee and reorganize the whole field of transplantation, has decided to take action. The office is charged with overseeing the entire transplant field, including organs, tissues and bone marrow, and is headed by Didier Houssin, a liver transplant surgeon at the Hôpital Cochin in Paris. Its board of directors will be chaired by embryologist Nicole Le Douarin, head of the Institut d'Embryologie near Paris. (Previously, oversight of this area was provided by various doctors' associations.)
Several board members even considered the advisability of a temporary ban on tissue transplants. One of the office's first tasks has been to commission a study to assess the risks associated with transplants. The study was completed in late February and, after due consideration, the board decided against instituting a temporary ban, believing that in spite of the present difficulties the benefits of tissue transplants still outweigh the disadvantages.

In France 25,000 transplant operations are performed every year, involving bone, cartilage, skin, heart-valve tissue and so on. Transplants of human dura mater, which were suspended in October of last year because of concerns about the transmission of Creutzfeld-Jakob disease, are still banned.

The new office, which has an annual budget of FFr54 million (about US\$11 million) has no intention of letting things get worse. One of its first actions has been to send a letter to about 15,000 transplant surgeons in France spelling out the regulations concerning transplant procedures and drawing attention to doctors' liabilities and responsibilities in this regard. Directors of publicly and privately funded medical facilities have also been sent questionnaires, which will enable the office to make a complete record of activities involving tissue transplants in France.

It will also have a role to play in public education and plans to run public awareness campaigns in an attempt to address the present organ and tissue shortage in France.

Another role will be to monitor the implementation of new bioethics laws, passed last July, for which there are strict new rules governing tissue sampling, preservation, transportation and use. The office will be in charge of enforcing safety measures and determining operational procedures for organ banks. "As soon as the law goes into effect we can report the organ banks or companies which are not complying with requirements, and, if needed, take the offenders to court," says Houssin.

Catherine Tastemain Paris 